\title{
Ograniczenie władzy rodzicielskiej przez umieszczenie dziecka w placówce opiekuńczo-wychowawczej w świetle badań aktowych ${ }^{2}$
}

Wpłynął: 22.01.2020. Akceptacja: 10.12.2021

\section{Streszczenie}

Celem niniejszego artykułu jest przedstawienie przebiegu postępowania w przedmiocie ograniczenia władzy rodzicielskiej przez umieszczenie dziecka w placówce opiekuńczo-wychowawczej na podstawie dokonanej analizy wyników badań własnych aktowych. Bardzo istotnym przedmiotem badań był zebrany w badanych sprawach materiał dowodowy. Zbadano m.in. najczęściej występujące w sprawach czynniki powodujące zagrożenie dobra dziecka. Niniejszy artykuł uwzględnia również rozważania teoretyczne na temat władzy rodzicielskiej oraz jej ograniczenia.

Słowa kluczowe: ograniczenie władzy rodzicielskiej, władza rodzicielska, przesłanka ograniczenia władzy rodzicielskiej, rodzice, małoletni, dzieci, dobro dziecka, badania własne aktowe, kwestionariusz.

1 Mgr Krystyna Seremak - Prawnicze Seminarium Doktorskie, Akademia Leona Koźmińskiego (Polska); e-mail: krysiaseremak@wp.pl; ORCID: 0000-0002-5032-0710.

2 Projekt badawczy nie jest finansowany przez żadną instytucję. 


\title{
Limitation of Parental Authority by Placing a Child in a Care and Educational Institution in the Light of Court Records Research ${ }^{3}$
}

\begin{abstract}
The purpose of this article is to present the course of the proceedings regarding the limitation of parental authority by placing the child in a care and educational institution based on the analysis of the results of own-study research. A very important subject of the research was evidence collected in the examined cases. Examined among others, the most frequent factors that pose a threat to the child's good. This article also takes into account theoretical considerations on parental authority and its limitations.
\end{abstract}

Keywords: Restriction of parental authority, parental responsibility, prerequisite for restricting parental authority, parents, minors, children, child's good, own research documents, questionnaire.

3 The research project is not funded by any institution. 


\section{Uwagi wstępne}

Instytucja władzy rodzicielskiej miała swoje początki w prawie rzymskim. Pierwotnie władza rodzicielska nie przysługiwała obojgu rodzicom, lecz wyłącznie ojcu (patriapotestas). Jak wskazuje W. Litewski „patriapotestas była bardzo silną władzą. Stanowiła w zasadzie pełne, jednolite władztwo, które bardzo wolno ulegało ograniczeniom. Ojciec rodziny posiadał prawo karcenia, a pierwotnie także prawo zabicia (ius vitae nesisque) członków rodziny. Pater familias mógł porzucić (expostio) nowonarodzone dziecko, jak również posiadał prawo sprzedaży dziecka" ${ }^{\prime \prime}$.

Kodeks rodzinny i opiekunczy jest podstawowym aktem prawnym regulującym stosunki zachodzące między rodzicami i dziećmi. Ogół praw i obowiązków rodziców przysługujących im wobec małoletniego dziecka w celu należytego sprawowania pieczy nad osobą dziecka i jego majątkiem, wychowania go oraz przygotowania do pracy odpowiednio do jego uzdolnień, nazywamy w polskim

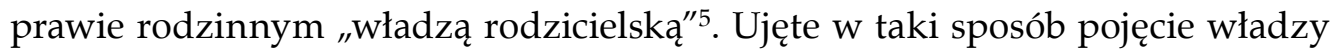
rodzicielskiej wynika z wykładni przepisów art. 95, 96 i 98 k.r.o. ${ }^{6}$. Kodeks ten nie zawiera ustawowej definicji władzy rodzicielskiej. W literaturze prawniczej istnieje zgodny pogląd, że przez pojęcie to należy rozumieć „ogół, zespół obowiązków i praw rodziców względem małoletniego dziecka, mających na celu zapewnienie mu należytej pieczy i strzeżenie jego interesów"7.

Podstawową zasadą prawa rodzinnego, wynikającą zarówno z orzecznictwa, jak i doktryny, jest ochrona dobra dziecka. Konstytucja RP w art. 72 ust. 1 stanowi, iż: „Rzeczpospolita Polska zapewnia ochronę praw dziecka. Każdy ma prawo żądać od organów władzy publicznej ochrony dziecka przed przemocą, okrucieństwem, wyzyskiem i demoralizacją". Sąd Najwyższy w uchwale z dnia 9 czerwca 1976 r., stwierdził, że „zasada dobra dziecka oznacza, iż jego interes przede wszyst-

\footnotetext{
$4 \quad$ W. Litewski, Rzymskie prawo prywatne, Warszawa 2003, s. 192-193.
}

$5 \quad$ M. Kosek, [w:] W. Stojanowska (red.), M. Kosek, Nowelizacja Prawa Rodzinnego na podstawie ustaw z 6 listopada 2008 r. i 10 czerwca 2010 r. Analiza - wykładnia - komentarz, Warszawa 2011, s. 227.

6 Ibidem.

7 W. Stojanowska, Władza rodzicielska, Warszawa 1988, s. 7; B. Dobrzański, [w:] B. Dobrzański, J. Ignatowicz (red.), Kodeks rodzinny i opiekuńczy. Komentarz, Warszawa 1975, s. 658; I. Długoszewska, Przesłanki oraz skutki ograniczenia i pozbawienia władzy rodzicielskiej, Warszawa 2012, s. 37; J. Ignatowicz, [w:] K. Pietrzykowski (red.), Kodeks rodzinny i opiekuńczy. Komentarz, Warszawa 2012, s. 861. 
kim rozstrzyga o tym, jak rodzice i opiekunowie powinni wykonywać swe obowiązki względem dzieci i rodziny, oraz w jakim kierunku powinny iść rozstrzygnięcia sądu w sprawach rodzinnych" ${ }^{\prime \prime}$. Konwencja o Prawach Dziecka z 1989 r. $\mathrm{w}$ art. 3 wskazuje potrzebę zabezpieczenia dobra dziecka przez wykonywanie obowiązków dotyczących wszystkich działań na rzecz dzieci. Organami podejmującymi się takich obowiązków są m.in. sąd oraz instytucje opieki społecznej. Według W. Stojanowskiej „niektóre przepisy prawa procesowego, podobnie jak materialnego, są normatywnym źródłem zasady ochrony dobra dziecka w jej odmianach szczegółowych"9 ${ }^{\prime \prime}$ Należy zauważyć, że w k.r.o. znajdują się przepisy regulujące ochronę dobra dziecka niezawierające terminu "dobro dziecka”. Warto podkreślić, że W. Stojanowska ${ }^{10}$ przeprowadziła dogłębną analizę wszystkich przepisów k.r.o. regulujących ochronę dobra dziecka. W stworzonej przez siebie tabeli ${ }^{11}$ zamieściła wykaz instytucji prawa rodzinnego oraz przyporządkowała do niego przepisy k.r.o., których celem jest urzeczywistnianie zasady ochrony dobra dziecka. Dokonała podziału tych przepisów na zawierające termin "dobro dziecka" lub synonim tego terminu, niezawierające terminu "dobro dziecka” oraz na takie, w których "dobro dziecka” występuje jako przesłanka materialno-prawna ${ }^{12}$. Ze wspomnianej tabeli wynika, że zasada dobra dziecka odnosi się do wszystkich przepisów regulujących sytuację dziecka, niezależnie od tego, czy zawierają one określenie „dobro dziecka”, czy też nie. Zdaniem J. Kosika „pośród zasad polskiego prawa rodzinnego, zwłaszcza tych, które przyświecają przepisom dotyczącym stosunków między rodzicami a dziećmi, jako przewodnia przedstawia się zasada dobra dziecka. Zasada ta ze względu na właściwy jej sens, przyświecać musi nie tylko przepisom, w których ją uwypuklono osobnym wyrażeniem, lecz $\mathrm{i}$ innym przepisom odnoszącym się do dzieci"13. Obecnie w prawie rodzinnym nie występuje definicja legalna pojęcia "dobro dziecka”. Pomimo tego literatura prawnicza podjęła próby określenia jego znaczenia. Dotychczas najbardziej precyzyjną definicję sformułowała W. Stojanowska, zgodnie z którą „termin »dobro dziecka«w rozumieniu przepisów prawa rodzinnego oznacza kompleks wartości o charakterze niematerialnym i materialnym niezbędnym do zapewnienia prawidłowego rozwoju fizycznego i duchowego dziecka oraz do należytego przygoto-

\footnotetext{
8 Uchwała SN z dnia 9 czerwca 1976 r., Zalecenia Kierunkowe, III CZP 46/75, OSNCP 1976, nr 9, poz. 184.

9 W. Stojanowska, Rozwód a dobro dziecka, Warszawa 1979, s. 18.

10 Ibidem, s. 15-18.

11 Ibidem, s. 17.

12 Ibidem.

13 J. Kosik, Problem przywrócenia władzy rodzicielskiej w świetle Kodeksu rodzinnego i opiekuńczego, NP 1973, nr 10, s. 1467-1468.
} 
wania go do pracy odpowiednio do jego uzdolnień, przy czym wartości te są zdeterminowane przez wiele różnorodnych czynników, których struktura zależy od treści stosowanej normy prawnej i konkretnej, aktualnie istniejącej sytuacji dziecka, zakładając zbieżność tak pojętego dobra dziecka z interesem społecznym"14.

Konstytucja RP w art. 48 ust. 2 stanowi, że: „ograniczenie praw rodzicielskich może nastąpić tylko w przypadkach określonych w ustawie i tylko na podstawie prawomocnego orzeczenia sądu." Wskazane w Konstytucji RP przypadki ograniczające władzę rodzicielską określone zostały w ustawie - Kodeks rodzinny i opiekuńczy z 1964 r. Sąd Najwyższy w uchwale z dnia 9 czerwca 1976 r. stwierdzil, że „ograniczenie władzy rodzicielskiej przez umieszczenie dziecka w placówce opiekuńczo-wychowawczej głęboko sięga w sferę uprawnień rodziców. Dlatego środek ten powinien być stosowany dopiero wtedy, gdy inne zarządzenia nie dały pożądanego wyniku lub gdy ze względu na szczególne okoliczności sprawy można uznać, że takiego wyniku nie dadzą. Wydanie wobec tego takiej decyzji jest niezbędne, gdy środowisko rodzinne wywiera negatywny wpływ na wychowanie dziecka albo gdy rodzice nie są $\mathrm{w}$ stanie poradzić sobie $\mathrm{z}$ codziennymi problemami wychowawczymi"15.

\section{Ograniczenie władzy rodzicielskiej w polskim prawie rodzinnym}

Władza rodzicielska powstaje z chwilą urodzenia się dziecka, a ustaje z chwilą uzyskania przez nie pełnoletności. Jednak zgodnie z art. $94 \S 1$ k.r.o., władza rodzicielska może ustać także na skutek śmierci dziecka lub rodziców, jak również utraty przez jednego z rodziców pełnej zdolności do czynności prawnych. Warto podkreślić, że jeżeli władza rodzicielska nie przysługuje jednemu z rodziców, nie zachodzi potrzeba powoływania osoby, która by tego rodzica zastępowała, ponieważ w myśl art. 93 § 1 k.r.o., władza rodzicielska przysługuje każdemu z rodziców „bez ograniczenia”. Wówczas władzę rodzicielską sprawuje tylko drugi z rodziców. Natomiast w przypadku, gdy żadnemu z rodziców nie przysługuje władza rodzicielska albo jeżeli rodzice są nieznani, sąd zgodnie z art. $94 \S 3$ k.r.o. ustanawia dla dziecka opiekę.

Kodeks rodzinny i opiekuńczy w art. 109 normuje instytucję ograniczenia władzy rodzicielskiej. Wyłączną przesłanką wydania przez sąd opiekuńczy zarządzeń na podstawie tego przepisu jest zagrożenie dobra dziecka. W. Stojanowska

\footnotetext{
14 W. Stojanowska, Rozwód a dobro..., s. 27.

15 Uchwała SN z dnia 9 czerwca 1976 r., Zalecenia Kierunkowe, III CZP 46/75, OSNCP 1976, nr 9, poz. 184.
} 
wskazała, że użycie przez ustawodawcę słowa „zagrożenie” w omawianym przepisie "pozwala na pewne działania ochronne już w sytuacjach zagrażających dobru dziecka, chociażby jego naruszenie jeszcze nie nastąpiło nawet $w$ najmniejszym stopniu (aspekcie)”16. Jak stwierdza H. Dolecki, „przepis ten zawiera dyrektywę nakazującą sądowi opiekuńczemu podjęcie ingerencji w sferę władzy rodzicielskiej już w razie potencjalnego zagrożenia dobra dziecka, by zapobiec ujemnym skutkom. Dobro dziecka nie musi więc być naruszone, wystarczy sam stan zagrożenia"17. Sąd Najwyższy w postanowieniu z dnia 29 października 1999 r. stwierdził, że „do ingerencji sądu doprowadza tylko takie nienależyte wykonywanie władzy rodzicielskiej, które zagraża dobru dziecka. Nienależyte wykonywanie władzy rodzicielskiej może obejmować także sytuacje, które nie zostały przez rodziców zawinione. Środki zastosowane przez sąd w stosunku do rodziców nienależycie wykonujących władzę rodzicielską nie mają charakteru penalnego, lecz są środkiem zmierzającym do ochrony dobra dziecka, które zostało zagrożone"18.

Umieszczenie dziecka w placówce opiekuńczo-wychowawczej jest jednym z najbardziej drastycznych środków ograniczenia władzy rodzicielskiej wynikających z art. $109 \S 2$ k.r.o. Jak podkreśla A. Zeliński, „dziecko zostaje wówczas nie tylko wyłączone $\mathrm{z}$ dotychczasowego środowiska rodzinnego, ale jednocześnie umieszczone w warunkach odbiegających w sposób istotny od warunków rodzinnych"19. Warto jednak podkreślić, że umieszczenie dziecka w placówce opiekuńczo-wychowawczej nie ma charakteru całkowitego odseparowania. Jak wskazuje J. Ignatowicz, rodzice w tym przypadku „w szczególności mogą i mają obowiązek interesowania się dzieckiem i warunkami, w jakich ono przebywa, informowania sądu o dostrzeżonych w tym zakresie uchybieniach; do nich też należy podejmowanie decyzji w istotnych sprawach dziecka, jak np. o konieczności przeprowadzenia zabiegu operacyjnego. Mają też prawo odwiedzania dziecka, zachowują bowiem oni uprawienie do osobistej z nim styczności, jeżeli sąd opiekuńczy i w tym zakresie nie wprowadził ograniczen" ${ }^{\prime 20}$.

Zgodnie z art. $112^{1} \S 1$ k.r.o. placówka opiekuńczo-wychowawcza, w której umieszczono dziecko w trybie art. $109 \S 2$ pkt 5 k.r.o., powinna wykonywać bieżącą

16 W. Stojanowska, Dobro dziecka jako instrument wykładni norm konwencji o prawach dziecka oraz prawa polskiego i jako dyrektywa jego stosowania, [w:] T. Smyczyński (red.), Konwencja o prawach dziecka. Analiza i wykładnia, Poznań 1999, s. 87.

17 H. Dolecki, [w:] H. Dolecki, T. Sokołowski (red.), Kodeks rodzinny i opiekuńczy. Komentarz, Warszawa 2013, s. 725.

18 Postanowienie SN z dnia 29 października 1999 r., I CKN 884/99, LEX nr 1125075; por. również postanowienie SN z dnia 28 kwietnia 2000 r., II CKN 452/00, LEX nr 52548.

19 A. Zieliński, Sądownictwo opiekuńcze w sprawach małoletnich, Warszawa 1975, s. 191.

20 J. Ignatowicz, op. cit., s. 933. 
pieczę nad dzieckiem, wychowywać je oraz reprezentować w sprawach związanych z jej wykonywaniem. Natomiast pozostałe obowiązki i prawa wynikające z władzy rodzicielskiej należą do rodziców dziecka. Warto podkreślić, że przez bieżącą pieczę należy rozumieć codzienną troskę o osobę dziecka, np. o zagwarantowanie mu bezpieczeństwa, opieki lekarskiej, racjonalnego żywienia, odpowiedniej odzieży, kulturalnych warunków bytu, warunków do systematycznego uczęszczania do szkoły, pomocy w usamodzielnianiu ${ }^{21}$.

\section{Przebieg postępowania sądowego w sprawach o ograniczenie władzy rodzicielskiej w świetle badań własnych aktowych ${ }^{22}$}

\section{Cel, zakres i metodologia badań}

W niniejszym artykule zostały przedstawione wyniki badań własnych aktowych przeprowadzonych w sprawach o ograniczenie władzy rodzicielskiej przez umieszczenie dziecka w placówce opiekuńczo-wychowawczej. Wyniki badań pozwoliły na szczegółową analizę przebiegu postępowania w sprawach o ograniczenia władzy rodzicielskiej od chwili wszczęcia postępowania do momentu wydania prawomocnego orzeczenia, jak też dokonania oceny prawidłowości zastosowania regulacji prawnej dotyczącej instytucji ograniczenia władzy rodzicielskiej. Zbadane sprawy stanowiły także źródło informacji o dowodach, które przeprowadzono $\mathrm{w}$ toku postępowania.

Badania własne aktowe objęły łącznie 100 spraw rozpoznanych w latach 2009-2016. Objęły one sprawy, które zakończyły się prawomocnym postanowieniem sądu w przedmiocie ograniczenia władzy rodzicielskiej przez umieszczenie dziecka w placówce opiekuńczo-wychowawczej. Badania zostały przeprowadzone w sądach różniących się znacząco liczbą prowadzonych postępowań oraz obszarem swojego działania.

Narzędziem badawczym, jakie wykorzystano, był kwestionariusz do badania akt sądowych, który zawierał 30 pytań i został podzielony na następujące działy:

21 M. Andrzejewski, Ochrona praw dziecka w rodzinie dysfunkcyjnej. Dziecko - rodzina - państwo, Kraków 2003, s. 232; J. Gajda, Kodeks rodzinny i opiekuńczy. Komentarz, wyd. 2, Warszawa 2000, s. 424; J. Ignatowicz, op. cit., s. 955.

22 Podstawą przedstawionej analizy badań własnych aktowych była praca magisterska autorki pt.: „Ograniczenie władzy rodzicielskiej przez umieszczenie dziecka w placówce opiekuńczo-wychowawczej w świetle badań aktowych", napisana pod kierunkiem prof. zw. dr hab. W. Stojanowskiej i obroniona w Akademii Leona Koźmińskiego w Warszawie w 2018 r. 
pierwszy zwierał informację ogólne, drugi odnosił się do informacji na temat rodziców oraz sytuacji $w$ rodzinie, trzeci dotyczył małoletnich, czwarty postępowania dowodowego, a piąty treści rozstrzygnięcia sądu.

\section{Informacje ogólne na temat badanych spraw}

Z analizy przeprowadzonych badań wynika, iż w 100 badanych sprawach głównym źródłem informacji o potrzebie wszczęcia postępowania w przedmiocie ograniczenia władzy rodzicielskiej była Policja oraz instytucje opieki społecznej (każda grupa wynosiła 30 przypadków). Prokurator złożył wniosek w jednej spośród zbadanych spraw. Tak samo było w przypadku rodzeństwa małoletniego oraz wujostwa. W przypadku rodziców wniosek został złożony w 4 sprawach - matka złożyła 2 wnioski, tyle samo ojciec. Sąsiedzi złożyli zawiadomienie w 2 sprawach, a dziadkowie w 3 sprawach. Instytucje opiekuncze złożyły wniosek w 12 sprawach. Szkoła wystąpiła z wnioskiem w 16 przypadkach. Instytucje służby zdrowia złożyły zawiadomienie w 8 sprawach. Z urzędu sąd wszczął postępowanie w 5 sprawach. Natomiast kuratorzy sygnalizowali problem w 29 sprawach. Warto zaznaczyć, że w 15 sprawach zawiadomienie kuratora sądowego o potrzebie ingerencji w wykonywanie władzy rodzicielskiej dotyczyło rodziny ograniczonej już w sprawowaniu tej władzy przez poddanie jej stałemu nadzorowi wykonywanemu przez kuratora.

Analiza przeprowadzonych badań własnych wykazała, iż postępowanie w przedmiocie ograniczenia władzy rodzicielskiej przez umieszczenie dziecka w placówce opiekuńczo-wychowawczej najczęściej trwało od 3 do 6 miesięcy - 31 badanych spraw. Natomiast jedynie w 6 przypadkach postępowanie trwało powyżej roku. Badania własne zostały przeprowadzone w sądach rejonowych w Warszawie oraz w Wałbrzychu. Warto podkreślić, że Sąd Rejonowy w Wałbrzychu w zdecydowanej większości spraw zmierzał do wyjaśnienia wszystkich zaistniałych okoliczności, przy czym nie przedłużał czasu trwania postępowania. Natomiast Sądy Rejonowe w Warszawie w znacznej części spraw prowadziły postępowanie nierzetelnie, co powodowało poważne braki w materiale dowodowym, a i tak trwało ono znacznie dłużej niż w Wałbrzychu. Przykładem może być fakt, że w niektórych sprawach sąd $\mathrm{w}$ Warszawie $\mathrm{w}$ trakcie trwania rozprawy nie sięgał po podstawowe informacje przy przesłuchaniu stron, tj. wiek, zawód, utrzymanie, problemy zdrowotne. Warto wspomnieć o sprawach, w których sąd nie przesłuchał ani jednego świadka.

Zarządzenie zabezpieczające wydawane przez sąd pozwala na zabezpieczenie dziecka przed zagrożeniem jego dobra do czasu wydania prawomocnego orzeczenia sądu. Dane zawarte w tabeli 1 wskazują, że w 89 spośród wszystkich zbadanych spraw sąd zastosował zarządzenie zabezpieczające. Sąd w kilku sprawach nie udzielił zabezpieczenia, ponieważ dziecko przebywało w czasie wszczęcia postę- 
powania w szpitalu lub w placówce opiekuńczo-wychowawczej. Jednak były także sprawy, w których sąd nie wydał zarządzenia zabezpieczającego, chociaż z zawiadomienia wynikało, że dobro dziecka jest zagrożone. $W$ badanych sprawach pojawiły się także przypadki, $w$ których sąd wydawał zarządzenie zabezpieczające o umieszczeniu dziecka w placówce opiekuńczo-wychowawczej, ale z powodu braku miejsc w placówce zmieniał zabezpieczenie na ustanowienie nadzoru kuratora sądowego.

Tabela 1. Zarządzenia zabezpieczające wydane przez sąd opiekuńczy w badanych sprawach

\begin{tabular}{ccc}
\hline Lp. & Zarządzenia zabezpieczające & w I.b. \\
\hline 1. & umieszczenie małoletniego w placówce opiekuńczo-wychowawczej & 76 \\
\hline 2. & ustanowienie nadzoru kuratora sądowego & 8 \\
\hline 3. & umieszczenie małoletniego w zawodowej rodzinie zastępczej & 2 \\
\hline 4. & ustalenie miejsca pobytu małoletniego u dziadków/wujostwa/matki/ojca & 3 \\
\hline 5. & nie udzielono zabezpieczenia & 11 \\
\hline & Ogółem & 100 \\
\hline
\end{tabular}

Źródło: Opracowanie własne.

\section{Sytuacja osobista i majątkowa stron w badanych sprawach}

\section{Informacje dotyczące rodziców oraz sytuacji w rodzinie}

Z przeprowadzonych badań własnych wynika, że w 100 badanych sprawach uczestniczyło 98 matek i 86 ojców. W 8 przypadkach zmarł ojciec, a w 2 przypadkach matka. Nie ustalono ojcostwa w 6 spośród badanych spraw. W aktach sprawy nie było informacji o wieku matki w 6 przypadkach, natomiast ojca w 21 przypadkach. Najliczniejszą grupę matek w badanych sprawach stanowiły kobiety znajdujące się w przedziale wiekowym od 18 do 30 lat - 36 przypadków. Najmniej liczną grupę matek stanowily kobiety w przedziale wiekowym 16-18 lat - 4 przypadki. Natomiast sytuacja ojców kształtowała się odmiennie. Najliczniejszą grupę ojców w badanych sprawach stanowili mężczyźni w przedziale wiekowym 30 lat do 40 lat - 19 spraw. Ojcowie w przedziałach wiekowych odpowiednio 40 do 45 lat oraz ponad 45 lat stanowili 28 przypadków. W żadnej spośród badanych spraw ojciec nie miał mniej niż 18 lat. Warto zaznaczyć, iż sąd nie zawsze ustalał dane o rodzicach, których postanowienie w przedmiocie ograniczenia władzy rodzicielskiej dotyczyło. Najbardziej widoczne było to w przypadku ojców, ponieważ 
ich wiek nie został ustalony w 21 spośród badanych spraw. Inaczej było w przypadku matek, gdzie brak informacji o wieku występował tylko w 6 sprawach. Należy zauważyć, że w badanych sprawach wystąpiły przypadki małoletnich matek w wieku poniżej 18 roku życia.

Analiza przeprowadzonych badań własnych wykazała, że w znacznej liczbie badanych spraw brak było informacji dotyczących wykształcenia zarówno matki - 28 przypadków, jak i ojca - 53 przypadki. Największą grupę matek stanowiły kobiety z wykształceniem podstawowym - 38 przypadków. Jedynie w dwóch spośród zbadanych spraw matka posiadała wykształcenie wyższe. Natomiast wykształcenie ojców kształtowało się inaczej niż w przypadku matek. W badanych sprawach wszyscy ojcowie posiadali co najmniej wykształcenie podstawowe. Najwięcej z nich posiadało wykształcenie zawodowe -25 przypadków. Tylko w jednym przypadku ojciec posiadał wykształcenie wyższe. Należy poddać krytyce bierność sądu w zakresie pozyskiwania informacji na temat wykształcenia rodziców. W przypadku danych dotyczących ojca w ponad połowie spraw w ogóle nie pozyskano takiej informacji. Należy zwrócić uwagę na to, że większość rodziców, wobec których wszczęto postępowanie w przedmiocie ograniczenia władzy rodzicielskiej, posiadała podstawowe albo zawodowe wykształcenie.

Przeprowadzone badania wykazały, że najczęściej występującym problemem u rodziców objętych postępowaniem był alkoholizm (matka 21 przypadków, ojciec 17 przypadków). Natomiast najrzadziej występującą dysfunkcją lub zaburzeniem w sferze stanu zdrowia były w przypadku matki schorzenia neurologiczne, choroby oczu i epilepsja, a w przypadku ojca niepełnosprawność fizyczna oraz schorzenia układu kostno-kręgowego (po 1 przypadku). W badanych sprawach u 9 matek i 5 ojców nie występowały żadne dysfunkcje lub zaburzenia stanu zdrowia. Informacje na temat rodzajów dysfunkcji lub zaburzeń nie wynikały z akt sprawy odpowiednio w przypadku matki w 43 sprawach i ojca w 69 sprawach. Należy zaznaczyć, że istotny wpływ na sposób wykonywania władzy rodzicielskiej przez rodziców mają ich predyspozycje psychofizyczne. W związku z powyższym należy negatywnie ocenić postawę sądu polegającą na tym, że w większości badanych spraw brakowało danych na temat dysfunkcji lub zaburzeń w sferze stanu zdrowia fizycznego i psychicznego występujących u rodziców. W badanych sprawach pojawiała się również duża rozbieżność w odniesieniu do informacji na temat dysfunkcji lub zaburzeń występujących u matki, a występujących u ojca. Zaledwie w 31 sprawach pojawiła się taka informacja dotycząca ojca. Natomiast w przypadku matek taka informacja znajdowała się w ponad połowie badanych spraw.

Tabela 2 wskazuje, że najczęściej rodzice małoletniego nigdy nie byli małżeństwem i mieszkali osobno - 25 przypadków. Zbliżony wynik występuje w przypadku rodziców, którzy nigdy nie byli małżeństwem i mieszkali wspólnie - 19 przy- 
padków. Rodzice byli małżeństwem i mieszkali wspólnie w 13 przypadkach, natomiast osobno w 6 przy padkach. Rodzice rozwiedzeni lub w separacji zamieszkujący osobno występowali w 17 sprawach. W badanych sprawach 10 rodziców zmarło przed wszczęciem postępowania. Matka była panną, a ojcostwo nie zostało ustalone w 6 przypadkach. Natomiast w 4 sprawach rodzice byli po rozwodzie/separacji i mieszkali wspólnie. Warto zaznaczyć, iż w badanych sprawach wystąpiły 3 przypadki, w których ojciec znajdował się w zakładzie karnym, z czego w 2 sprawach rodzice byli małżeństwem, a w jednej nie byli małżeństwem. W jednej sprawie rodzice byli rozwiedzeni i mieszkali wspólnie, ale ojciec miał zasądzoną eksmisję. $Z$ tabeli 2 wynika, że problem w zakresie wykonywania władzy rodzicielskiej w znacznym stopniu występuje $\mathrm{u}$ rodzin niepełnych, a więc takich, w których dziecko wychowywane było przez jednego rodzica.

Tabela 2. Sytuacja prawna między rodzicami w badanych sprawach

\begin{tabular}{ccc}
\hline Lp. & Sytuacja prawna między rodzicami & w I.b. \\
\hline 1. & rodzice byli małżeństwem i mieszkali wspólnie & 13 \\
\hline 2. & rodzice byli małżeństwem i mieszkali osobno & 6 \\
\hline 3. & rodzice nigdy nie byli małżeństwem i mieszkali wspólnie & 19 \\
\hline 4. & rodzice nigdy nie byli małżeństwem i mieszkali osobno & 25 \\
\hline 5. & rodzice byli po rozwodzie/separacji i mieszkali wspólnie & 4 \\
\hline 6. & rodzice byli po rozwodzie/separacji i mieszkali osobno & 17 \\
\hline 7. & matka była panną, a ojcostwo nie zostało ustalone & 6 \\
\hline 8. & jedno z rodziców zmarło & 10 \\
\hline & Ogółem & 100 \\
\hline
\end{tabular}

Źródło: Opracowanie własne.

Analiza wyników przeprowadzonych badań wskazuje, że źródła utrzymania rodziców różnią się w znaczny sposób. Najczęstszym źródłem utrzymania w przypadku matek był sposób niezarobkowy (renty, emerytury, zasiłki, alimenty etc.) - 41 spraw. Natomiast u ojców była to praca dorywcza, na którą składała się praca na podstawie umowy, jak i praca bez umowy - 22 przypadki. Najrzadszym źródłem utrzymania u matek była praca dorywcza, u ojców sposoby niezarobkowe - 9 przypadków. Ponadto 6 matek pozostawało na utrzymaniu innego podmiotu. Źródło utrzymania rodziców nie wynikało z akt sprawy u matek w 14 przypadkach i u ojców w 45 przypadkach. W badanych sprawach wystąpiły także dwa przy- 
padki, w których rodzic przebywał w zakładzie karnym oraz jeden przypadek, w którym oboje rodzice byli bezdomnymi. Trzeba zaznaczyć, że informacje dotyczące źródła utrzymania rodziców są szczególnym rodzajem danych, ponieważ zazwyczaj to sami rodzice dostarczają ich przy wywiadzie środowiskowym lub przez składanie wyjaśnień. W konsekwencji nie można oceniać negatywnie braku takiej informacji, ponieważ ustalenie takich danych jest możliwe tylko wtedy, jeżeli rodzic bierze udział w postępowaniu. Warto wspomnieć, że w badanych sprawach wystąpiły przypadki, w których rodzic nie brał udziału w postępowaniu, dlatego też stawało się niemal niemożliwe uzyskanie takiej informacji.

Z analizy wyników badań wynika, że w większości spraw małoletni przebywał z matką, która sprawowała nad nim władzę rodzicielską sama (26 przypadków) lub wspólnie z konkubentem albo ojczymem (10 przypadków). Natomiast w mniejszości spraw małoletni przybywał u samego ojca lub ojca i jego konkubiny (3 przypadki). Miejscem przebywania małoletniego była także instytucja opiekuńcza - 13 spraw i szpital - 12 spraw.

Przeprowadzone badania wykazały, że małoletni najczęściej przebywał w złych warunkach mieszkaniowych - 42 przypadki. Natomiast w 21 spośród badanych spraw warunki mieszkaniowe, w których przebywał małoletni, były dobre. W 5 przypadkach warunki te były bardzo złe, a tylko w jednej sprawie były bardzo dobre. Badanie warunków mieszkaniowych nie dotyczyło małoletnich w 25 sprawach, ponieważ przebywali oni w instytucjach opiekuńczych albo w szpitalu. Warunki mieszkaniowe, $w$ jakich przebywał małoletni, nie wynikały z akt sprawy w 6 przypadkach. Warto zaznaczyć, że w większości spraw, w których małoletni przebywał w wyżej wymienionych instytucjach, jednym z decydujących czynników do umieszczenia w nich dziecka były właśnie warunki mieszkaniowe w domu rodzinnym małoletniego, które kształtowały się na bardzo niskim poziomie.

\section{Informacje dotyczące małoletnich}

Z przedstawionych wyników badań wynika, że najczęściej rodzice posiadali jedno małoletnie dziecko, które pozostawało pod ich władzą rodzicielską - 62 spośród badanych spraw. W 27 przypadkach pod władzą rodzicielską rodziców pozostawało dwoje dzieci. $W$ badanych sprawach rodzice posiadali troje dzieci - 7 przypadków, a czworo - 3 przypadki. Tylko w jednej sprawie rodzice posiadali pięcioro małoletnich dzieci. Analiza materiału badawczego pozwala na stwierdzenie, że najczęściej problemy wychowawcze dotyczyły rodzin małodzietnych. Należy zaznaczyć, że w badanych sprawach wśród grupy rodziców posiadających tylko jedno dziecko występowały przypadki rodziców mających więcej niż jedno dziecko, ale postępowanie nie odnosiło się do tych dzieci, ponieważ została tym rodzicom już wcześniej ograniczona władza rodzicielska nad nimi. Oznacza to, że w bada- 
nych sprawach sądy opiekuńcze należycie realizowały swój obowiązek, jakim jest ochrona dobra dziecka, ponieważ nie lekceważyły dysfunkcji pojawiających się już wcześniej w danej rodzinie.

W badanych sprawach liczba dzieci, które w chwili wszczęcia postępowania $\mathrm{w}$ przedmiocie ograniczenia władzy rodzicielskiej pozostawały pod władzą rodzicielską rodzica/rodziców wynosiła 154 w tym 80 dziewczynek i 74 chłopców. Najczęściej wiek dzieci wynosił do 1 roku - 28 przypadków oraz od 12 do 15 lat - 27 przypadków. Również liczną grupę tworzyły dzieci w wieku od 6 do 9 lat - 25 przypadków. W 19 sprawach wystąpiły dzieci w wieku od 1 roku do 3 lat. Taki sam wynik odnosił się do dzieci w wieku 3 do 6 lat. Najstarsze dzieci mające ponad 15 lat tworzyły najmniej liczną grupę -15 spraw. Wobec tego można przyjąć, że przyczyny ograniczenia władzy rodzicielskiej pojawiały się już w wieku niemowlęcym małoletniego. Trzeba zaznaczyć, że w niektórych sprawach w środowisku rodzinnym już wcześniej dochodziło do nieprawidłowego wykonywania władzy rodzicielskiej.

Z analizy przeprowadzonych badań wynika, że najwięcej małoletnich dzieci uczęszczało do szkoły podstawowej - 52 przypadki. Do szkoły nie chodziło 51 małoletnich ze względu na wiek (dzieci do 6 lat). Do gimnazjum uczęszczało 32 małoletnich, natomiast do przedszkola 9. Najmniej małoletnich chodziło do szkoły ponadgimnazjalnej i do klasy zerowej (po 4 przypadki). Warto wspomnieć, że w badanych sprawach występowały przypadki, w których małoletni powtarzał klasę podstawową albo gimnazjalną kilkukrotnie. Tylko w dwóch sprawach brakowało w aktach sprawy informacji na temat rodzaju szkoły, do jakiej uczęszczał małoletni. Wskazuje to na duże zainteresowanie sądów opiekunczych zdobyciem podstawowych informacji na temat małoletniego dziecka.

Analiza materiału badawczego wskazuje, że w znacznej liczbie badanych spraw sąd nie gromadził informacji o dysfunkcjach somatycznych oraz intelektualnych występujących u małoletnich - 53 przypadki. Małoletni nie wykazywali żadnej dysfunkcji w 45 sprawach. Najczęściej występującą w badanych sprawach dysfunkcją były uszkodzenia narządów wzroku/słuchu/mowy - 11 przypadków. W badanych sprawach jednostkowo wystąpiło schorzenie krtani, urologiczne, układu rozrodczego, epilepsji, zespołu Downa, choroby skóry, zaburzenia układu pokarmowego oraz niskiej odporności organizmu. Dlatego też należy krytycznie ocenić postawę sądu zaniechania gromadzenia informacji o występowaniu u małoletnich dzieci zaburzeń w sferze rozwoju fizycznego i psychicznego. Celem postępowania w przedmiocie ograniczenia władzy rodzicielskiej jest ochrona dobra małoletniego. Jednak, analizując powyższe wyniki badań, trudno jest zrozumieć, jak można chronić dobro dziecka bez posiadania istotnych informacji na temat jego stanu zdrowia. 
Z przeprowadzonych badań wynika, że w większości spraw małoletni nie sprawiał problemów wychowawczych - 93 przypadków. W badanych sprawach 40 małoletnich sprawiało problemy wychowawcze. Informacja taka nie wynikała z akt sprawy w 21 przypadkach. Należy zauważyć, że brak problemów wychowawczych w znacznej mierze powiązany jest z wiekiem małoletnich. Dzieci do 6 roku życia przeważnie nie sprawiają problemów wychowawczych w sposób świadomy. Dlatego też dzieci w takim wieku nie podlegały temu kryterium. Należy także zaznaczyć, że niektóre dzieci stwarzały więcej niż jeden problem wychowawczy. Najczęstszym problemem wychowawczym, jaki sprawiał małoletni, były wagary - 27 przypadków. W badanych sprawach złe zachowanie w szkole dotyczyło 17 małoletnich, natomiast nieposłusznych wobec rodziców było 13 małoletnich. Wystąpiły przypadki małoletnich, którzy uciekali z domu oraz stosowali agresję słowną i fizyczną wobec rówieśników (po 9 przypadków). Kontakty ze środowiskiem patologicznym posiadało 9 małoletnich. Pojawiły się także przypadki małoletnich dopuszczających się czynów sprzecznych z prawem oraz palących papierosy (po 7 przypadków). Używania alkoholu dopuściło się 4 małoletnich, natomiast używania narkotyków 3 małoletnich. Pojawiły się również przypadki małoletnich, którzy podjęli próbę samobójczą oraz posiadali kontakty seksualne z dorosłymi (po 2 przypadki).

Wskazane powyżej zachowania małoletnich stanowią przejawy demoralizacji zgodnie $\mathrm{z}$ art. $4 \S 1$ ustawy - Postępowanie w sprawach nieletnich ${ }^{23}$, dlatego też ingerencja sądu $\mathrm{w}$ wykonywanie władzy rodzicielskiej w tego rodzaju sprawach jest jak najbardziej zasadna. Należy również zaznaczyć, iż w badanych sprawach kłopoty wychowawcze, jakie sprawiali małoletni, miały niewielki wpływ na sposób wykonywania władzy rodzicielskiej i rzadziej stanowiły przyczynę ingerencji sądu opiekuńczego w wykonywanie władzy rodzicielskiej.

\section{Postępowanie dowodowe i rozstrzygnięcie w badanych sprawach}

\section{Informacje dotyczące postępowania dowodowego}

Analiza danych przedstawionych w tabeli 3 wskazuje, że w ponad połowie spraw czynnikiem negatywnie wpływającym na proces wychowania dziecka występującym w środowisku rodzinnym było nadużywanie alkoholu przez rodziców małoletniego - 52 spraw. Natomiast w połowie spraw rodzice byli niewydolni wychowawczo - 50 przypadków. Rodzice nie interesowali się dzieckiem w 33 przypadkach. Do konfliktów w rodzinie dochodziło w 18 sprawach. Rodzice nie troszczyli się o rozwój fizyczny i duchowy dziecka w 16 przypadkach, a przemoc fizyczną stosowali w 14 sprawach. Rodzice utrzymywali kontakty ze środowiskiem

23 Tekst jedn. Dz.U. z 2018, poz. 969 z późn. zm. 
patologicznym w 13 przypadkach, natomiast chorowali na przewleką chorobę, wpływającą negatywnie na proces wychowania dziecka w 8 przypadkach. Wystąpiły również przypadki przemocy psychicznej stosowanej przez rodziców oraz ich bezdomności (po 5 przypadków), a także odbywania długotrwałej kary pozbawienia wolności przez jednego z rodziców oraz porzucenia dziecka (po 3 przypadki). W badanych sprawach wystąpiły także negatywne zachowania mające charakter jednostkowy - używanie narkotyków przez rodziców, ich śmierć, długotrwały pobyt za granicą oraz rozwiązły, pasożytniczy i niemoralny tryb życia, a także zgwałcenie dziecka przez członka rodziny.

Tabela 3. Czynniki negatywnie wpływające na proces wychowania dziecka występujące $\mathrm{w}$ środowisku rodzinnym w badanych sprawach

\begin{tabular}{|c|c|c|}
\hline Lp. & Czynniki negatywne & w l.b. \\
\hline 1. & przemoc fizyczna & 14 \\
\hline 2. & przemoc psychiczna & 5 \\
\hline 3. & nadużywanie alkoholu & 52 \\
\hline 4. & używanie narkotyków & 1 \\
\hline 5. & brak zainteresowania dzieckiem & 33 \\
\hline 6. & niewydolność wychowawcza rodziców & 50 \\
\hline 7. & konflikty w rodzinie & 18 \\
\hline 8. & kontakty rodziców ze środowiskiem patologicznym & 13 \\
\hline 9. & śmierć rodzica & 1 \\
\hline 10. & długotrwały pobyt za granicą & 1 \\
\hline 11. & przewlekła choroba rodzica & 8 \\
\hline 12. & nieporadność życiowa rodzica & 3 \\
\hline 13. & rozwiązły, pasożytniczy i niemoralny tryb życia rodziców & 1 \\
\hline 14. & brak troski o rozwój fizyczny i duchowy dziecka & 16 \\
\hline 15. & odbywanie długotrwałej kary pozbawienia wolności & 3 \\
\hline 16. & zgwałcenie dziecka przez członka rodziny & 1 \\
\hline 17. & bezdomność & 5 \\
\hline 18. & porzucenie dziecka & 3 \\
\hline & Ogółem* & 228 \\
\hline
\end{tabular}

* Liczba ogółem nie odpowiada liczbie 100 badanych spraw, ponieważ w większości spraw występował więcej niż jeden czynnik negatywnie wpływający na proces wychowania dziecka.

Źródło: Opracowanie własne. 
Warto zauważyć, że powyższe czynniki są głównymi przyczynami ograniczenia władzy rodzicielskiej przez umieszczenie dziecka w placówce opiekuńczo-wychowawczej, ponieważ najbardziej zagrażają dobru dziecka. Ponadto w pewnych przypadkach uzasadniają zastosowanie przez sąd ingerencji w postaci pozbawienia rodziców władzy rodzicielskiej. Warto podkreślić, iż niektóre czynniki występujące w środowisku rodzinnym nie mają tak ogromnego wpływu na dobro dziecka, jak czynniki zamieszczone $\mathrm{w}$ tabeli 3 .

Tabela 4. Dowody przeprowadzone przez sąd w toku postępowania w przedmiocie ograniczenia władzy rodzicielskiej

\begin{tabular}{ccc}
\hline Lp. & Przeprowadzone dowody & w I.b. \\
\hline 1. & zeznania świadków & 57 \\
\hline 2. & dowód z dokumentu & 54 \\
\hline 3. & dowód z akt innej sprawy sądowej & 45 \\
\hline 4. & opinia RODK (obecnie OzSS) & 17 \\
\hline 5. & wywiad środowiskowy przeprowadzony przez kuratora sądowego & 83 \\
\hline 6. & wywiad środowiskowy przeprowadzony przez pracowników opieki społecznej & 16 \\
\hline 7. & opinia szkoły & 10 \\
\hline 8. & opinia instytucji opiekuńczej & 10 \\
\hline 9. & opinia poradni psychologiczno-pedagogicznej & 22 \\
\hline 10. & dowód z przesłuchania stron & 6 \\
\hline 11. & Ogółem* & 5 \\
\hline 12. & & 60 \\
\hline
\end{tabular}

* Liczba ogółem nie odpowiada liczbie 100 badanych spraw, ponieważ w większości spraw sąd przeprowadzał więcej niż jeden dowód.

Źródło: Opracowanie własne.

Dane przedstawione w tabeli 4 wskazują, że niewątpliwie najczęściej przeprowadzanym dowodem $\mathrm{w}$ toku postępowania w przedmiocie ograniczenia władzy rodzicielskiej był wywiad środowiskowy przeprowadzany przez kuratora sądowego - 83 przypadki. Również w znacznej liczbie spraw zostały wykorzystane dowody z przesłuchania stron - 60 spraw, zeznania świadków - 57 spraw oraz dowody w postaci dokumentu (odpisy aktu urodzenia dzieci, aktu małżeństwa oraz zgonu rodziców) - 54 sprawy. W prawie połowie spraw został przeprowadzony dowód 
z akt innej sprawy sądowej - 45 przypadków, natomiast dowód z opinii instytucji opiekuńczej w 22 sprawach. Było zaledwie 17 spraw, w których sąd przeprowadził dowód z opinii RODK (obecnie OZSS). W niewielu mniej, bo w 16 sprawach, dowód stanowiły wywiady środowiskowe przeprowadzane przez pracowników opieki społecznej. Skorzystano także z dowodu w postaci opinii szkoły oraz opinii lekarskiej (po 10 przypadków). Najmniej wykorzystywanym dowodem w toku postępowania był wywiad środowiskowy przeprowadzany przez funkcjonariusza Policji oraz opinia poradni psychologiczno-pedagogicznej. Odnosząc się do wyników tabeli 4, należy stwierdzić, że w toku postępowania w przedmiocie ograniczenia władzy rodzicielskiej wykorzystywane dowody nie były znacząco zróżnicowane. Najczęściej korzystano z dowodu w postaci wywiadu środowiskowego przeprowadzanego przez kuratora sądowego. Na krytykę zasługuję fakt, że sądy w tak małym stopniu wykorzystywały dowody z ekspertyzy RODK/OZSS, z opinii szkoły, a także poradni psychologiczno-pedagogicznej, które mogłyby stanowić istotny dowód w postępowaniu o ograniczenie władzy rodzicielskiej. Gdyby te dowody w badanych sprawach były częściej przeprowadzane, być może miałoby to wpływ na rozstrzygnięcie sądu i zamiast ograniczenia władzy rodzicielskiej sąd orzekłby jej pozbawienie w trybie art. 111 k.r.o.

\section{Informacje o treści rozstrzygnięcia sądu w badanych sprawach}

Przeprowadzona analiza wyników badań świadczy o tym, że orzeczenie sądu w przedmiocie ograniczenia władzy rodzicielskiej przez umieszczenie dziecka w placówce opiekuńczo-wychowawczej najczęściej dotyczy obojga rodziców - 52 przypadki, a najrzadziej ojca -8 przypadków, przy czym znacząco dotyczy matki w 40 spośród badanych spraw. Warto zaznaczyć, że była jedna sprawa, w której zawiadomienie o potrzebie ingerencji w wykonywanie władzy rodzicielskiej dotyczyło obojga rodziców, ale matka zmarła w trakcie postępowania. Wobec tego orzeczenie sądu dotyczyło tylko ojca. Należy także podkreślić, że pojawiły się sprawy, w których jeden z rodziców został już pozbawiony władzy rodzicielskiej, dlatego postępowanie w przedmiocie ograniczenia władzy rodzicielskiej go nie dotyczyło.

\section{Uwagi końcowe}

Przedstawiona powyżej analiza badań własnych aktowych umożliwiła szczegółową charakterystykę przebiegu postępowania sądowego w przedmiocie ograniczenia władzy rodzicielskiej przez umieszczenie dziecka w placówce opiekuńczo-wychowawczej. Zebrane dane dotyczyły zarówno informacji podstawowych, jak i szczegółowych dotyczących małoletnich dzieci oraz rodziców. 
Przeprowadzone badania własne aktowe wykazały, że w znacznej liczbie spraw rodzice posiadali zawodowe lub podstawowe wykształcenie. Warto zaznaczyć, że według M. Heine poziom wykształcenia rodziców ma istotny wpływ na sposób wychowania dziecka, na pobudzanie w nim zainteresowania nauką oraz na stymulowanie rozwoju jego aspiracji i dążeń, co jednak nie oznacza, że wszyscy rodzice lepiej wykształceni są lepszymi wychowawcami i lepiej realizują proces wychowawczy ${ }^{24}$. W większości badanych spraw sytuacja materialna rodziny była zła, a małoletnie dzieci przebywały w złych warunkach mieszkaniowych. Najczęstszą przyczyną zagrożenia dobra dziecka było nadużywanie alkoholu przez rodziców. Jednak w kilku sprawach pojawiły się dzieci trudne wychowawczo, które były zagrożone demoralizacją. W tych przypadkach rodzice często sami inicjowali potrzebę wszczęcia postępowania w przedmiocie ograniczenia władzy rodzicielskiej, ponieważ w dalszym ciągu nie mogli sobie poradzić z ich wychowywaniem, pomimo zastosowania już przez sąd innych środków ingerujących w wykonywanie władzy rodzicielskiej.

Jak już wcześniej zauważono, badania własne aktowe wykazały, że sąd w toku postępowania dosyć często sięgał po szczegółowe informacje na temat małoletnich oraz rodziców. Jednak w przy padku danych dotyczących informacji o rodzajach dysfunkcji somatycznych oraz intelektualnych występujących u małoletnich dzieci, a także informacji dotyczących wykształcenia rodziców w większości spraw sąd nie skorzystał z takiej informacji.

Podsumowując, obowiązująca regulacja prawna dotycząca instytucji ograniczenia władzy rodzicielskiej jest właściwie ukształtowana. Przepis art. 109 k.r.o. zawiera podstawową przesłankę ograniczenia władzy rodzicielskiej - dobro dziecka. Dzięki takiej konstrukcji sąd ingeruje w wykonywanie władzy rodzicielskiej, gdy zagrożone jest dobro dziecka, bez względu na to, czy jego źródłem jest zawinione lub niezawinione działanie rodziców, czy też zachowanie samego dziecka. Nie ma potrzeby wprowadzania jakichkolwiek zmian legislacyjnych, natomiast należy poprawić stosowanie przez sąd obowiązujących przepisów. Dotyczy to głównie rzetelności i wnikliwości w prowadzenia postępowania dowodowego w omawianych sprawach, co zapewnia dokonanie przez sąd właściwego wyboru rozstrzygnięcia, zgodnego z dobrem dziecka.

24 M. Heine, Pedagogiczne następstwa ograniczenia wtadzy rodzicielskiej, Wrocław 1991, s. 17. 


\section{Bibliografia}

\section{Literatura}

Andrzejewski M., Ochrona praw dziecka w rodzinie dysfunkcyjnej. Dziecko - rodzina - państwo, Kraków 2003.

Długoszewska I., Przestanki oraz skutki ograniczenia i pozbawienia władzy rodzicielskiej, Warszawa 2012.

Dobrzański B., [w:] B. Dobrzański, J. Ignatowicz (red.), Kodeks rodzinny i opiekuńczy. Komentarz, Warszawa 1975.

Dolecki H., [w:] H. Dolecki, T. Sokołowski (red.), Kodeks rodzinny i opiekuńczy. Komentarz, wyd. 2, Warszawa 2013.

Gajda J., Kodeks rodzinny i opiekuńczy. Komentarz, wyd. 2, Warszawa 2000.

Heine M., Pedagogiczne następstwa ograniczenia władzy rodzicielskiej, Wrocław 1991.

Ignatowicz J., [w:] K. Pietrzykowski (red.), Kodeks rodzinny i opiekuńczy. Komentarz, wyd. 3, Warszawa 2012.

Kosek M., [w:] W. Stojanowska (red.), M. Kosek, Nowelizacja Prawa Rodzinnego na podstawie ustaw z 6 listopada 2008 r. i 10 czerwca 2010 r. Analiza - wyktadnia - komentarz, Warszawa 2011.

Kosik J., Problem przywrócenia władzy rodzicielskiej w świetle Kodeksu rodzinnego i opiekuńczego, NP 1973, 10.

Litewski W., Rzymskie prawo prywatne, Warszawa 2003.

Stojanowska W., Dobro dziecka jako instrument wykładni norm konwencji o prawach dziecka oraz prawa polskiego i jako dyrektywa jego stosowania, [w:] T. Smyczyński (red.), Konwencja o prawach dziecka. Analiza i wykładnia, Poznań 1999.

Stojanowska W., Wtadza rodzicielska, Warszawa 1988.

Stojanowska W., Rozwód a dobro dziecka, Warszawa 1979.

Zieliński A., Sądownictwo opiekuńcze w sprawach małoletnich, Warszawa 1975.

\section{Akty prawne}

Konstytucja Rzeczypospolitej Polskiej z dnia 2 kwietnia 1997 r. (Dz.U. Nr 78, poz. 483 z późn. zm.).

Ustawa z dnia 25 lutego 1964 r. - Kodeks rodzinny i opiekuńczy (Dz.U. Nr 9, poz. 59 z późn. zm.).

Ustawa z dnia 19 grudnia 1975 r. o zmianie ustawy Kodeks rodzinny i opiekuńczy (Dz.U. Nr 45, poz. 234).

Ustawa z dnia 6 stycznia 2000 r. o Rzeczniku Praw Dziecka (Dz.U. Nr 6, poz. 69 z późn. $z m$.).

Ustawa z dnia 22 maja 2018 r. - Postępowanie w sprawach nieletnich (Dz.U. poz. 969 z późn. $\mathrm{zm}$.).

Konwencja o prawach dziecka, przyjęta przez Zgromadzenie Ogólne Narodów Zjednoczonych z dnia 20 listopada 1989 r. (Dz.U. z 1991 r. Nr 120, poz. 526 z późn. zm.). 


\section{Orzecznictwo}

Uchwała SN z dnia 9 czerwca 1976 r., Zalecenia Kierunkowe, III CZP 46/75, OSNCP 1976, nr 9, poz. 184.

Postanowienie SN z dnia 29 października 1999 r., I CKN 884/99, LEX nr 1125075.

Postanowienie SN z dnia 28 kwietnia 2000 r., II CKN 452/00, LEX nr 52548. 